\title{
Biologically Active Substances from the Genus Artemisia
}

\author{
R. X. Tan*, W. F. Zheng, and H. Q. Tang \\ Institute of Biotechnology, Department of Biological Science \& Technology, Nanjing University, Nanjing, P. R. China
}

Received: June 20, 1997; Revision accepted: January 2, 1998

\begin{abstract}
Artemisia species, widespread in nature, are frequently utilized for the treatment of diseases such as malaria, hepatitis, cancer, inflammation, and infections by fungi, bacteria, and viruses. Furthermore, some Artemisia constituents were found to be potential insecticides and allelopathic chemicals. This genus is receiving growing attention presumably due to: (i) the diversified biology and chemistry of the constituents, (ii) the frequent application in traditional medical practice, and (iii) the rich source of the plant material. This review summarizes mainly the biological results obtained in the past decade. The significance and trends in this field are briefly discussed.
\end{abstract}

Key words: Artemisia, Compositae, biologically active substances.

\section{Introduction}

The genus Artemisia L., one of the largest genera belonging to the Compositae family consisting of more than 350 species, is predominantly distributed in the northern temperate region of the world in the $0-50 \mathrm{~cm}$ precipitation area. As summarized by different groups ( $1-3)$, many species have been used since ancient times as folk remedies for some treatment purposes (reducing phlegm, relieving cough, invigorating blood circulation, stopping pain, inducing sweat, diuresis, antihypertension, anthelminthic, antitoxic, and antiallergy). According to the literature, over 260 Artemisia species have been investigated to reveal that they contain many classes of secondary metabolites including terpenoids, flavonoids, coumarins, glycosides, sterols, and polyacetylenes.

During the intensive investigation of the chemical components of Artemisia genus, much renewed attention was paid to bioactive constituents. As reported, some substances from the genus were shown to be antimalarial, antiviral, antitumor, antipyretic, antihemorrhagic, anticoagulant, antianginal, antioxidant, antihepatitis, antiulcerogenic, antispasmodic, anticomplementary, and interferon-inducing. This article deals principally with bioactive constituents characterized in the past decade from Artemisia species in order to obtain a better understanding of the biological significance of this large genus.

Planta Medica 64 (1998) 295-302

cc Georg Thieme Verlag Stuttgart $\cdot$ New York

\section{Biologically Active Substances}

Bioactive compounds found in this genus include mono-(23$\mathbf{2 5}$ ) and sesquiterpenoids (1-22), flavonoids (26-57), coumarins (59-64), isoprenylcoumaric acid derivatives (65-68), caffeoylquinic acids (70-73), acetylenes (74-77), sterols $(78,79)$, a phenoxychromene (57), an acetophenone glucoside (58), a phenylpropene (69), methyl jasmonate (80), and $\gamma$ tocopherol $(\mathbf{8 1})$. The plant sources and bioactivities are summarized in Table 1, and the biologically active parts and fractions in Table 2.

\section{Antimalarial}

Mainly due to the multidrug resistance developed by Plasmodium species, malaria remains a serious problem with approximately 300 million cases annually in the world $(83,84)$. As shown in Table 1, the antimalarial constituents from Artemisia L. are sesquiterpenes, coumarins, and polymethoxyflavones. The renewed attention to artemisinin (1) and its related compounds indicate that the antimalarial mechanism of this class of drugs is based on an unusual mode of action leading to the alkylation of malaria-specific proteins (90). Quite interestingly, artemisinin was also detected in A. apiacea (87) and $A$. lancea (88). This disclosed clearly that the presence of artemisinin is not limited to A.annua. To some extent, screenings of other Artemisia species for the artemisininrelated compounds are desired for broadening the source of these valuable products particularly when the synthesis of them is very costly. Some flavonoids 26-29, possessing weaker activities against Plasmodium falciparum, can potentiate the antiplasmodial activity of artemisinin (4). This finding suggested a possible way for increasing the effectiveness of artemisinin and its analogues. Other antimalarial constituents, $1\left(S^{*}\right)$-hydroxy- $\alpha$-bisaboloxide A acetate (22) and isofraxidin (61), were obtained from A. abrotanum (8). However, the mechanism and the dependence of the antimalarial activity on the structure are still obscure.

\section{Antitumor}

The antitumor natural products characterized from Artemisia genus include mono- and sesquiterpenes and phenolic compounds. Artemisinin (1) and its semi-synthetic analogues have been disclosed to possess stereochemistry-dependent cytotoxicity (86). A continuation of this topic is desired for the understanding of quantitative structure-activity relationships 
Table 1 Bioactive substances from Artemisia species ${ }^{1}$.

Plant Sources Bioactive Compounds

A. abrotonum L.

A. absinthium L.

A. annua $\mathrm{L}$.

A. argyi Levl. et Van.

A. austriaca Jacq.

A. barrelieri

A. borealis Pall.

A. caerulescens subsp. gallica A. capillaris Thunb.

A. cina Berg. ex Pol.

A. douglasiana Bess.

A. giraldii Pamp.

A. iwayomagi Kitam.

A. judaica

A. monosperma

A. motano Pamp.

A. myriontha Wall. ex Bess.

A. nilagirica Pamp.

A. pacifico

A. princeps Pamp. antimalarial ${ }^{2}: 22$ and 61 ( $\mid C_{50}: 5.09$ and $7.95 \mu \mathrm{g} / \mathrm{ml}$, resp.)

spasmolytic ${ }^{3}: 44-46\left(\mathrm{EC}_{50}: 20-30 \mu \mathrm{M}\right)$

References

antitumor ${ }^{4}: \mathbf{2 6}^{4}$

antipyretic: 79

antimalarial: $1\left(\mathrm{IC}_{50}: 3 \times 10^{-8} \mathrm{M}\right), 3,26-29\left(\mathrm{IC}_{50}: 2.4-6.5 \times 10^{-5} \mathrm{M}\right)$

antibacterial: 4

anti-inflammatory: $\mathbf{6 0}$

angiotensin-converting enzyme inhibitory: $47\left(\mathrm{IC}_{50}: 150 \mu \mathrm{M}\right), 48$

(4)

$(8-10)$

(11)

allelopathic: 1, bis(1-hydroxy-2-methylpropyl)phthalate, ABA, Me-ABA

$(13,14)$

antitumor: 1 and 31

antitumor ${ }^{6}$ : 10-12

(15)

antihemorrhagic: $43, \beta$-sitosterol

antispasmodic: 6

Aedes aegypti repellent: 9-hydroxy-1,8-cineole

anti-inflammatory ${ }^{7}: 15^{8}, 17-19$

antimicrobial ${ }^{9}: \mathbf{7 4}, 75$

$(21,22)$

lavicidal ${ }^{10}: 74,75$

antipyretic (in rats): 13, 14, 20

antitumor $^{11}: 30,57$

antiviral: 77

antihepatitis: $33,34,59,63,64$

anticoagulant: 60,62

antianginal ${ }^{12}: 62$

choleretic $^{13}: 62,65-67$

immunosuppressive: $62\left(10^{-6} \mathrm{M}\right.$ to $\left.3 \times 10^{-4} \mathrm{M}\right)$

antifeedant: 69, 76, 77

plant growth regulatory: $68^{14}, 78^{15}, G A 3, A B A$

antibacterial (Bacillus subtilis and $B$. cereus): 13

antiulcerogenic: 7

antimicrobial ${ }^{16}: 16,37-39$

antioxidant: 70

antispasmodic ${ }^{17}: 30$

antispasmodic $^{18:} 32,43$

hemostatic: 71-73

antitumor: $\mathbf{5}$

repellant to Culex pipiens quinquefosciotus: 77

antimicrobial ${ }^{19}: \mathbf{7 4}$

anticoagulant ${ }^{20}$ : sulfated polysaccharides ${ }^{21}$

\footnotetext{
${ }^{1}$ In vitro activity unless stated otherwise.

${ }^{2}\left[{ }^{3} \mathrm{H}\right]$-hypoxanthine incorporation assay.

${ }^{3}$ On carbacholine-induced contractions of the guinea pig trachea.

${ }^{4}$ In mice and rats with experimental tumors.

${ }^{5}$ Against melanoma B16.

${ }^{6}$ Inhibiting the growth of Sarcoma 100 cells in female BALB/cx DBA mice.

${ }^{7}$ Tested on carrageenan-induced rat paw edema.

8 Prepared from 19 with zinc and acetic acid.

${ }^{9}$ On bioautographic assay and minimum amounts (in $\mu \mathrm{g}$ ) of 74 required for the growth inhibition were: 1.25 (Cladosporium cucumrinum), 25 (Candida albicans), 25 (Bacillus subtilis), 50 (Staphylococcus aureus) and 100 (Klebsiello pneumoniae), and of 75: 1.25 (Cladosporium cucumrinum).

${ }^{10} / \mathrm{C}_{100}: 100 \mathrm{ppm}$, to larvae of Aedes aegypt.

${ }^{11} \mathrm{IC}_{50}(\mu \mathrm{g} / \mathrm{ml}): 30: 3.2$ (Hela cells) and 0.54 (Ehrlich cells), 57: 3.4 (Hela cells) and 0.03 (Ehrilich cells).

12 Tested both in vitro (29) and in vivo (30).

13 In Wistar rats.

${ }^{14}$ Promoting at $5 \times 10^{-5} \mathrm{M}$ rice root growth to $180 \%$ of the control.

${ }^{15}$ Inhibiting completely at $8 \times 10^{-6} \mathrm{M}$ the germination of seeds of millet, pansy, cabbage and carrot.

${ }^{16} \mathrm{MIC}(\mu \mathrm{g} / \mathrm{ml})$ : 16: 50 (Staphylococcus aureus), 50 (Candida tropicalis), 75 (Gecotrichun candidun), 50 (Aspergillus niger), 75 (A. flavus).

${ }^{17}$ Reducing, at concentrations up to $3 \times 10^{-4} \mathrm{M}$, the amplitude and tone of the phasic contractions of the isolated guinea-pig ileum.

${ }^{18} \mathrm{On}$ isolated rat smooth muscle and in concentrations from $10^{-7}$ to $3 \times 10^{-7} \mathrm{M}$.

${ }^{19} \mathrm{MIC}(\mu \mathrm{g} / \mathrm{ml})$ by the agar diffusion method: 25 [Bacillus subtilis (UA 2-27)], 50 [Staphylococcus aureus (UA 9-29)], 100 [Klebsiella pneumoniae (UA 3-9)] and [Condida albicans (UA 9-7)].

${ }^{20}$ The anticoagulant activity was assessed by measuring activated partial thromboplastin time of the tested sample.

${ }^{21}$ Prepared by the treatment of natural acidic polysaccharides with pyridine and chlorosulfonic acid complex.

22 Structurally clear.
} 
Table 1 Cont.

\begin{tabular}{|c|c|c|}
\hline Plant Sources & Bioactive Compounds & References \\
\hline A. scoparia Waldst. et Kit. & choleretic (in rats): p-hydroxyacetophenone & $(52)$ \\
\hline A. sieversiana Ehrhart er Willd. & antitumor $^{4}: 26^{5}, \mathbf{2 7}$ & (6) \\
\hline A. subdigitata Mattf. & antianginal: 9 & (54) \\
\hline A. sublessin-giana & antimicrobial: $35,36,41,56$ & (55) \\
\hline Krash. ex Poljak & enzyme regulator: $20,41,42,50,56$ & $(56,57)$ \\
\hline
\end{tabular}

Table 2 Bioactive parts and fractions derived from Artemisia species.

\begin{tabular}{|c|c|c|}
\hline Plant Sources & Bioactive Parts (Activities) or Fraction & References \\
\hline Artemisia species & glycoproteins (interferon-inducing) & (59) \\
\hline A. absinthium $\mathrm{L}$. & aqueous $\mathrm{MeOH}$ extract (hepatoprotective) & (60) \\
\hline A. afra & essential oils (antibiotic and antioxidant) & (61) \\
\hline A. annua $\mathrm{L}$. & extract (antipyretic) & (11) \\
\hline A. apiacea Hance & acidic polysaccharides (anticoagulant) & $(50)$ \\
\hline A. arborescens & aqueous extract (antispasmodic) & (62) \\
\hline A. asiatica Nakai ex Pamp. & essential oils (allelopathic) & (63) \\
\hline $\begin{array}{l}\text { A. asiatica Nakai ex Pamp. } \\
\text { nakai Pamp. }\end{array}$ & $\begin{array}{l}\text { essential oils (antibacterial) } \\
\text { hot-water extract (antibacterial) }\end{array}$ & $(64)$ \\
\hline \multirow[t]{2}{*}{ A. copillaris Thunb. } & HPLC fractions (cytocidal) & (23) \\
\hline & ether, EtOAc and $\mathrm{MeOH}$ extracts (antioxidant) & (31) \\
\hline A. cina Berg. ex Poljak. & total flavonoids (antitumor, antifungal) & (65) \\
\hline A. dracunculus $\mathrm{L}$. & essential oils (antifungal and antibacterial) & (66) \\
\hline A. edgeworthii Balakr. & essential oils (antibacterial) & (66) \\
\hline A. gmelini Web. ex Stechm. & essential oils (antifungal and antibacterial) & $(66)$ \\
\hline A. herba-alba & essential oils (antifungal and antibacterial) & $(67,68)$ \\
\hline A. indica Willd. & extract (antifungal) & $(69)$ \\
\hline \multirow[t]{2}{*}{ A. iwayomogi Kitam. } & extract (hepatoprotective) & $(70)$ \\
\hline & polysaccharide parts (immunomodulating and antitumor) & (71) \\
\hline \multirow[t]{2}{*}{ A. jacutica } & essential oils (anti-inflammatory) & $(72)$ \\
\hline & essential oils (antifungal and antibacterial) & $(67)$ \\
\hline A. laciniato Willd. & essential oils (antibacterial) & $(66)$ \\
\hline A. mocrocephala Jacq. ex Bess. & essential oils (anti-inflammatory) & (72) \\
\hline A. maritima $\mathrm{L}$. & essential oils (antifungal and antibacterial) & (66) \\
\hline A. molinieri & flavonoid fraction (antifungai) & (73) \\
\hline A. moorcroftiana Wall. ex DC. & essential oils (antifungal and antibacterial) & (66) \\
\hline A. nilagrica Pamp. & essential oils (antifungal and antibacterial) & $(66)$ \\
\hline A. parviflora Buch.-Ham. ex Rox. & essential oils (antifungal and antibacterial) & $(66)$ \\
\hline A. pontica $\mathrm{L}$. & essential oils (anti-inflammatory) & (72) \\
\hline A. princeps Pamp. & extract (antiaging) & (74) \\
\hline \multirow[t]{2}{*}{ A. princeps var. orientalis Hara } & essential oils (allelopathic, antifungal and antibacterial) & (75) \\
\hline & MeOH extract (anti-inflammatory and analgesic) & $(76,77)$ \\
\hline & plant residues (allelopathic) & $(78)$ \\
\hline \multirow{4}{*}{ A. scoparia Waldst. et Kirt. } & essential oils (antifungal and antibacterial) & $(66)$ \\
\hline & total flavonoids (antitumor) & $(65)$ \\
\hline & aqueous $\mathrm{MeOH}$ extract (hepatoprotective) & $(79,80)$ \\
\hline & essential oils (antifungal and antibacterial) & $(66)$ \\
\hline \multirow[t]{3}{*}{ A. selengensis Turcz. er Bess. } & flavonoids (antifungal) & (73) \\
\hline & polysaccharide parts (immunomodulating and antitumor) & (71) \\
\hline & extract (hepatoprotective) & $(81)$ \\
\hline A. sieversiana Willd. & essential oils (anti-inflammatory) & (72) \\
\hline A. stolonifera Komar. & flavonoids (antifungal) & (73) \\
\hline A. sublessingiana Krasch. er Poljak. & total flavonoids (antifungal) & (65) \\
\hline A. tournefortiana Reichb. & essential oils (antifungal and antibacterial) & (66) \\
\hline A. tridentata Nutt. & dry leaves (repellent to beetles) & (82) \\
\hline
\end{tabular}


and the mode of action. However, this elegant work did exhibit the possibility that artemisinin-related compounds, in addition to being used as antimalarial drugs, could find application in the treatment of some cancers. Other sesquiterpenes, e.g., guaianolide (5), seco-guaianolides (10-12), and eudesmanolide (21), also showed antitumor activities (Table 1). But more investigations are needed for the insight into the mechanism and the structure-activity relationship. Capillarisin (57), the only 2-phenoxychromene derivative found so far in the Artemisia genus, and its semi-synthetic analogues exhibited in vivo antitumor activities (24). A recent review described the distribution of 2-phenoxychromene compounds in the plant kingdom (95).

\section{Antiviral}

The antiviral constituents from Artemisia species were limited to plant sterols and acetylenes $(25,96)$. Furthermore, a few flavonoids like fisetin (47) and quercetin (50) were found to be inhibitors of HIV replication in H9 cells (89). To our knowledge, many Artemisia plants are being used for the treatment of the virus-related disease such as influenza indicating that more antiviral Artemisia constituents are to be characterized.

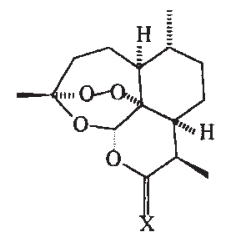

1 (artemisinin) $X=0$ 2 (arteether) $\mathrm{X}=\mathrm{H}, \beta-\mathrm{OEt}$<smiles>C=C1C(=O)O[C@H]2C1CCC1(C)O[C@@]13CC=C(C)C23</smiles>

5 (arglabin)

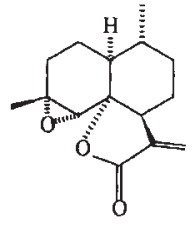

3 (arteannuin B)<smiles>[Y]C1CC(C)=C2C(=O)C=C(C)[C@@H]2[C@@H]2OC(=O)C([Y])[C@H]12</smiles>

$6 \mathrm{R}=\mathrm{O}$ ang, $\mathrm{X}=\mathrm{CH}_{2}$

$7 \mathrm{R}=\mathrm{H}, \mathrm{X}=\mathrm{CH}_{2}$

$8 \mathrm{R}=\mathrm{H}, \mathrm{X}=\alpha-\mathrm{Me}, \mathrm{H}$

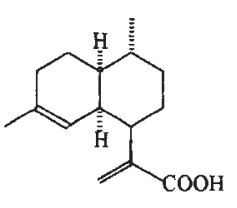

4 (artemisic acid)<smiles>[R]C1(CCC(C)=O)C(=C)C(=O)O[C@H]1C1([R])C(=O)C(O)C=C1C</smiles><smiles></smiles>

$10 \mathrm{R}=\beta-H, \mathrm{R}^{\prime}=\alpha-\mathrm{H} 13$ ( $\alpha$-santonin) $\mathrm{R}=\alpha-\mathrm{Me} 15 \Delta^{3}, \mathrm{R}=\mathrm{H}, \mathrm{X}=\mathrm{O}, \mathrm{Y}=\mathrm{H}, \boldsymbol{\alpha}-\mathrm{Me}$ $11 \mathrm{R}=\beta-H, \mathrm{R}^{\prime}=\beta-H \quad 14$ ( $\beta$-santonin) $\mathrm{R}=\beta-\mathrm{Me} 16 \Delta^{4}, \mathrm{R}=\mathrm{OH}, \mathrm{X}=\mathrm{O}, \mathrm{Y}=\mathrm{H}, \beta-\mathrm{Me}$ $12 \mathrm{R}=\alpha-\mathrm{H}, \mathrm{R}^{\prime}=\alpha-\mathrm{H}$<smiles>C[C@H]1C(=O)O[C@@H]2[C@@H]3[C@@H](O)C=CC(=O)[C@@]3(C)CC[C@@H]21</smiles>

19 (barrelin)<smiles>C=C1CCC(O)[C@]2(C)CCC3[C@@H](C)C(=O)O[C@]3(O)[C@H]12</smiles>

20 (arsubin)

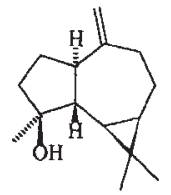

9 (spathulenol)

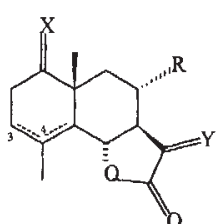<smiles>CC1=CC(O)C(C2CCC([O-])C(C)(C)O2)CC1</smiles>

22 (1(S*)-hydroxy-abisaboloxide $\mathrm{A}$ acetate<smiles>[2H]C1=CC(C)C(=O)CC1C(C)C</smiles>

23 (3 $\alpha$-hydroxycarvotagenone) 25 (sautolina alcohol) $\mathrm{R}=\alpha-\mathrm{OH}$

24 (3ß-hydroxycarvotagenone) $\mathrm{R}=\boldsymbol{\beta}-\mathrm{OH}$<smiles>[R]c1cc(-c2oc3c([R8])c([R4])c([R4])c([R2])c3c(=O)c2[R1])c([R6])c([R7])c1[R6]</smiles>

\begin{tabular}{|c|c|c|c|c|c|c|c|c|c|c|}
\hline & names & R1 & $\mathrm{R} 2$ & $\mathbf{R}^{3}$ & $\mathrm{R}^{4}$ & R5 & $\mathrm{R}^{6}$ & R7 & R8 & $\mathrm{Rg}$ \\
\hline 26 & arteme & OMe & $\mathrm{OH}$ & $\mathrm{OMe}$ & OMe & $\mathrm{H}$ & H & $\mathrm{OMe}$ & OMe & $\mathbf{H}$ \\
\hline 27 & netin & OMe & $\mathrm{OH}$ & $\mathrm{OMe}$ & OMe & H & H & OMe & $\mathrm{OH}$ & $\mathrm{H}$ \\
\hline 28 & chrysoplenol-D & OMe & $\mathrm{OH}$ & $\mathrm{OMe}$ & OMe & H & $H$ & $\mathrm{OH}$ & $\mathrm{OH}$ & $H$ \\
\hline 29 & cirsilir & $\mathrm{H}$ & $\mathrm{OH}$ & $\mathrm{OMe}$ & $\mathrm{OMe}$ & H & $H$ & $\mathrm{OMe}$ & $\mathrm{OH}$ & $H$ \\
\hline 10 & cirsim & H & $\mathrm{OH}$ & $\mathrm{OMe}$ & OMe & H & $\mathrm{H}$ & $\mathbf{H}$ & $\mathrm{OH}$ & $\mathrm{H}$ \\
\hline 31 & $\begin{array}{l}\text { quercetagetin } 6,7,3^{\prime}, 4^{\prime}- \\
\text { tetramethyl ether }\end{array}$ & $\mathrm{OH}$ & $\mathrm{OH}$ & $\mathrm{OMe}$ & OMe & $H$ & H & $\mathrm{OMe}$ & $\mathrm{OMe}$ & \\
\hline 32 & eriodictyol 7-methyl ether & H & $\mathrm{OH}$ & H & OMe & $\mathrm{H}$ & H & $\mathrm{OH}$ & $\mathrm{OH}$ & H \\
\hline 3 & eupat & H & $\mathrm{H}$ & $\mathrm{OMe}$ & OMe & $\mathrm{H}$ & $H$ & $\mathrm{OH}$ & $\mathrm{OH}$ & H \\
\hline 34 & arcapillin & H & $\mathrm{H}$ & OMe & $\mathrm{OMe}$ & $H$ & $\mathrm{OH}$ & H & $\mathrm{OH}$ & $\mathrm{OMe}$ \\
\hline 5 & & H & $\mathrm{OH}$ & $\mathrm{OMe}$ & $\mathrm{OH}$ & $\mathrm{H}$ & $H$ & $\mathrm{OMe}$ & $\mathrm{OH}$ & $H$ \\
\hline 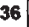 & chrysoeriol & $H$ & $\mathrm{OH}$ & $\mathrm{H}$ & $\mathrm{OH}$ & $\mathrm{H}$ & $H$ & OMe & H & H \\
\hline & & H & $\mathrm{OH}$ & H & $\mathrm{H}$ & $\mathrm{OMe}$ & H & OMe & OMe & $\mathrm{OH}$ \\
\hline & & H & H & $\mathrm{OH}$ & $\mathrm{OH}$ & $\mathrm{H}$ & $\mathrm{H}$ & $\mathrm{OMe}$ & $\mathrm{OH}$ & OMe \\
\hline & & $\ddot{H}$ & $\mathrm{OH}$ & $H$ & $\mathrm{OH}$ & $\mathrm{H}$ & $\mathrm{H}$ & OMe & $\mathrm{OH}$ & OMe \\
\hline 40 & genkwanin & H & $\mathrm{OH}$ & $H$ & $\mathrm{OMe}$ & H & $\mathrm{H}$ & H & $\mathrm{OH}$ & H \\
\hline 11 & hispid & $H$ & $\mathrm{OH}$ & OMe & $\mathrm{OH}$ & H & $H$ & $H$ & $\mathrm{OH}$ & $H$ \\
\hline 42 & jaceosidin & H & $\mathrm{OH}$ & OMe & $\mathrm{OH}$ & $H$ & $H$ & OMe & $\mathrm{OH}$ & $H$ \\
\hline 43 & eupatilin & $\mathrm{H}$ & $\mathrm{OH}$ & OMe & $\mathrm{OH}$ & $H$ & $H$ & $\mathrm{OMe}$ & OMe & H \\
\hline 4 & & $\mathrm{OMe}$ & $\mathrm{OH}$ & OMe & OMe & $\mathrm{H}$ & H & $\mathrm{OH}$ & OMe & H \\
\hline 7 & & OMe & $\mathrm{OH}$ & OMe & $\mathrm{OH}$ & H & $H$ & $\mathrm{OH}$ & OMe & H \\
\hline 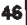 & & OMe & $\mathrm{OH}$ & $H$ & $\mathrm{OH}$ & H & $H$ & $\mathrm{OH}$ & $O M e$ & H \\
\hline 47 & fisetin & $\mathrm{OH}$ & $\mathrm{H}$ & $H$ & $\mathrm{OH}$ & $H$ & H & $\mathrm{OH}$ & $\mathrm{OH}$ & H \\
\hline 48 & patuletin 3,7-dirhamnoside & Prhan & $\mathrm{OH}$ & OMe & Orhan & $H$ & $\mathrm{H}$ & $\mathrm{OH}$ & $\mathrm{OH}$ & $H$ \\
\hline 49 & acacetin & & $\mathrm{OH}$ & $\mathrm{H}$ & $\mathrm{OH}$ & $\stackrel{\mathrm{H}}{\mathrm{H}}$ & $H$ & H & OMe & $\mathrm{H}$ \\
\hline so & querce & $\mathrm{OH}$ & $\mathrm{OH}$ & $\mathrm{H}$ & $\begin{array}{l}\mathrm{OH} \\
\mathrm{OH}\end{array}$ & $\begin{array}{l}H \\
H\end{array}$ & H & $\mathrm{OH}$ & $\mathrm{OH}$ & $H$ \\
\hline 51 & quercetin 3-O-galactoside & Ogal & $\mathrm{OH}$ & $H$ & $\begin{array}{l}\mathrm{OH} \\
\mathrm{OH}\end{array}$ & & $\begin{array}{l}H \\
H\end{array}$ & $\begin{array}{ll}\mathrm{OH} \\
\mathrm{OH}\end{array}$ & $\begin{array}{l}\mathrm{OH} \\
\mathrm{OH}\end{array}$ & $\begin{array}{l}\mathrm{H} \\
\mathrm{H}\end{array}$ \\
\hline 52 & quercetin 3-O-robinoside & Orob & $\mathrm{OH}$ & H & $\begin{array}{ll}\mathrm{OH} \\
\mathrm{OMe}\end{array}$ & 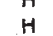 & $H$ & $\mathrm{OH}$ & $\mathrm{OH}$ & H \\
\hline 53 & isorhamnetin & $\mathrm{OH}$ & $\mathrm{OH}$ & $H$ & $\begin{array}{l}\mathrm{OMe} \\
\mathrm{OMe}\end{array}$ & $\mathrm{H}$ & $H$ & $\mathrm{OH}$ & $\mathrm{OH}$ & H \\
\hline $\begin{array}{l}54 \\
55\end{array}$ & $\begin{array}{l}\text { isorhamnetin 3-O-galactoside } \\
\text { isorhamnetin 3-O-robinoside }\end{array}$ & $\left|\begin{array}{l}\text { Ogal } \\
\text { Orob }\end{array}\right|$ & $\begin{array}{l}\mathrm{OH} \\
\mathrm{OH}\end{array}$ & $\begin{array}{l}\mathrm{H} \\
\mathrm{H}\end{array}$ & OMe & $\stackrel{\mathrm{H}}{\mathrm{H}}$ & $\mathrm{H}$ & $\mathrm{OH}$ & $\mathrm{OH}$ & $\mathrm{H}$ \\
\hline 56 & isorhamnetin 3-O-rutinoside & Orut & $\mathrm{H}$ & $\mathrm{H}$ & $\mathrm{OH}$ & $\mathrm{H}$ & $\mathrm{H}$ & $\mathrm{OMe}$ & $\mathrm{OH}$ & $\mathrm{OH}$ \\
\hline
\end{tabular}

\section{Antihepatitis and hepatoprotective}

Table 1 has indicated that antihepatitis and hepatoprotective constituents from Artemisia species were monoterpenes, flavonoids, and coumarins. Monoterpenes 23 and 24 from A. douglasiana showed a pronounced cytoprotective activity, and the preliminary investigation of the structure-activity relationship indicated that the presence of hydroxy groups in this pair of epimers could stop the activity (40). The extract of A. capillaris also had an intense suppressive activity in $\mathrm{CCl}_{4^{-}}$ induced liver lesion in mice with the active components identified as eupatolitin (33), arcapillin (34), esculin (59), scopolin (63), and isoscopoletin- $\beta$-O-glucoside (64) (26). However, more pharmacological investigations are necessary for evaluating the potential as antihepatitis and hepatoprotective agent(s).

\section{Antifungal}

The search of novel antifungal agents has become an urgent task because the incidence of opportunistic systemic mycoses is increasing remarkably (97). As given in Table 1, the anti- 
fungal constituents from Artemisia species include flavonoids, polyacetylenes, and sesquiterpenes. However, caution has to be taken in comparing their antifungal activities obtained on different bioassay models. The polyacetylenes $\mathbf{7 4}$ and $\mathbf{7 5}$ have been found to exhibit antifungal activity against plant and human pathogenic fungi. It seems that acetylation of the hydroxy groups can diminish the antifungal activity $(21,22)$. Further work in this respect will be helpful for understanding the dependence of the activity on the structure.

\section{Antibacterial}

Antibacterial substances characterized from Artemisia species were monoterpenes, flavonoids, and sesquiterpene lactones. A well-known antiprotozoal drug, $\alpha$-santonin (13), showed a strong antibacterial activity (39). Artemisinic acid (4), a precursor for the semi-synthesis of artemisinin (1) (98), was shown to be antibacterial, too (11). This preliminary finding<smiles>COc1c(O)cc2oc(Oc3ccc(O)cc3)cc(=O)c2c1O</smiles>

57 (capillarisin)<smiles>COc1cc(O)c(C(C)=O)c(OC)c1</smiles>

58<smiles>[R]c1cc2ccc(=O)oc2c([R])c1[R]</smiles>

\begin{tabular}{c|l|c|c|c}
\hline Compounds & Names & $\mathrm{R}_{1}$ & $\mathrm{R}_{2}$ & $\mathrm{R}_{3}$ \\
\hline $\mathbf{5 9}$ & esculin & $\mathrm{OH}$ & $\mathrm{OH}$ & $\mathrm{H}$ \\
60 & scopoletin & $\mathrm{OMe}$ & $\mathrm{OH}$ & $\mathrm{H}$ \\
$\mathbf{6 1}$ & isofraxidin & $\mathrm{OMe}$ & $\mathrm{OH}$ & $\mathrm{OMe}$ \\
62 & scoparone & $\mathrm{OMe}$ & $\mathrm{OMe}$ & $\mathrm{H}$ \\
63 & scopolin & $\mathrm{OMe}$ & $\mathrm{Oglu}$ & $\mathrm{H}$ \\
$\mathbf{6 4}$ & isoscopoletin O-glucoside & Oglu & $\mathrm{OMe}$ & $\mathrm{H}$ \\
\hline
\end{tabular}<smiles>CC(C)=CCc1cc(/C=C/C(=O)O)cc2c1OC(C(C)CO)C2</smiles><smiles>CC(=O)C=Cc1ccc(O)c(C(=O)C=C(C)C)c1</smiles>

68 (capillarol)<smiles>[R]OC1C([R10])CC(O)(C(=O)O)CC1[R10]</smiles>
71 72 (neochlorogenic acid) 73 65 (artepillin)

70 (chlorogenic acid)<smiles>[R]CC(C)=CCc1cc(C=CC(=O)O)cc(CC=C(C)C)c1O</smiles>

66 (capillartemisin $\mathrm{B}_{1}$ ) $\mathrm{R}=\mathrm{OH}$ 67 (artepillin $\mathrm{C}$ ) $\quad \mathrm{R}=\mathrm{H}$<smiles>C=CCc1ccc(O)c(OC)c1</smiles>

69 (methyleugenol)
$R^{1}=$ caffeoyl, $R 2=R^{3}=H$ $R 1=R 2=$ caffeoyl, $R 3=H$ $\mathrm{R} 1=\mathrm{R} 3=$ caffeoyl, $\mathrm{R} 2=\mathrm{H}$ $R 1=H, R 2=R 3=$ caffeoyl gave hints for broadening the applications of these two important Artemisia constituents.

\section{Anti-inflammation}

As indicated by Tables $\mathbf{1}$ and $\mathbf{2}$, the anti-inflammatory compounds found in the genus include mainly coumarins, sesquiterpene lactones, and essential oils. Barrelierin (17), artemalin (18), and barrelin (19) from A. barrelieri, and desoxyvulgarin (15) (obtained by reduction of barrelin with zinc and acetic acid) exhibited anti-inflammatory activities. Investigation of the structure-activity relationship showed that the $\alpha$ methylene- $\gamma$-lactone moiety was not essential for the antiinflammatory effect, but alterations in other parts of the molecule affected the activity substantially (20).

\section{Antipyretic}

$\alpha$ - and $\beta$-santonin (13 and 14 ) and arsubin (20) caused a decrease in rectal temperature of rats in a way similar to dopamine (23). The sterol 24- $\zeta$-ethylcholesta-7,22-dien-3 $\beta$-ol (79) was found to be antipyretic (7). However, more pharmacological attention is desired for assessing the potential as antipyretic agent(s).

\section{Hemostatic, antihemorrhagic and anticoagulant}

It seems that some polar constituents of the Artemisia species possess these activities. The hemostatic principles of $A$. montana and $A$.princeps were identified as 3,5-, 3,4-, and 4,5-di0 -caffeoylquinic acids (71-73) (47). This rationalized their 
applications as hemostatic agents in traditional Chinese medical practice. Acidic polysaccharides from A. apiacea and $A$.princeps were shown to be anticoagulant (50). However, this investigation needs to be continued for the pharmaceutical potential of these products.

\section{Spasmolysis and antianginal}

Scoparone from A.capillaris was found to be a competitive antagonist of nor-epinephrine like nitroglycerine (29). But the mode of action and structure-activity relationship are to be highlighted. Furthermore, some flavonols like 30, 32, 44-46 also possessed spasmolytic activity $(5,45,46)$. The results are not comparable since they were obtained on different models. Moreover, sesquiterpenes such as $\mathbf{6}$ and $\mathbf{9}$ were anti-spasmodic (54). More studies are needed for an insight into the mechanism and the structure-activity relationship.

\section{Antiulcerogenic and choleretic}

The guaianolide dehydroleucodin (7) from A. douglasiana was protective against gastric ulceration whereas deacetoxylmatricarin (8) from A. mendozana did not show any cytoprotective activity. Further comparative studies indicated that the $\alpha$-methylene- $\gamma$-lactone unit was essential for the activity (41). As to choleretic substances, scoparone (62), artepillin (65), capillartemisin $\mathrm{B}_{1}(\mathbf{6 6})$, and artepillin $C(\mathbf{6 7})$ from $A$. capillaris were shown to be choleretic in Wistar rats (31). These findings rationalized that A. capillaris, called "Yingchenhao" in Chinese, is being often used for choleretic purposes.

\section{Anticomplementary}

Two acidic and three neutral polysaccharides from $A$.princeps were found to be anticomplementary. The two acidic ones had a rhamnogalacturonan main-chain which was mostly substituted with arabino-3,6-galactan and arabino-4-galactan at position four of rhamnose. Furthermore, the mode of action of the anticomplementary acidic heteroglycans has been also investigated (51).

\section{Antioxidant}

Antioxidant constituents characterized from Artemisia species were in most cases phenolic compounds. Chlorogenic acid (70) from A. iwayomogi was recently disclosed to possess an antioxidant activity comparable to that of $\mathrm{L}$-ascorbic acid (44). A comparative study of its analogues such as 71-73 is desirable for their potential antioxidant activities.

\section{Analgesic, antidiabetic and antiparasitic}

The information about the constituents having these activities is quite limited (Tables $\mathbf{1}$ and $\mathbf{2}$ ). What has been reported so far concerning these aspects are preliminary results such as bioassay of fractions (or even extracts) and ordinary phytochemical analyses.

\section{Enzyme regulator}

The enzyme regulators found in Artemisia species are mainly phenolic compounds. The flavonoids $\mathbf{4 7}$ and $\mathbf{4 8}$ from $A$. annua were capable of inhibiting the activity of angiotensin-converting enzyme. This observation may be of value in hypertension treatment (12). Flavonoids $\mathbf{4 0 - 4 2}$ and 50 as well as an eudesmanolide $\mathbf{2 0}$ from $A$. sublessingiana exerted modulating effects on the sodium, potassium-ATPase, and the results demonstrated the potential for new cardiotonic drugs ( 56 , 57).

\section{Interferon-inducing and immunomodulating}

Many Artemisia species contain interferon-inducing glycoproteins with molecular weights ranging from $5 \times 10^{5}$ to $10 \times$ $10^{5}(59)$. The polysaccharide fractions from $A$. selengensis and $A$. iwayomogi were shown to have immunomodulating activity (71). These reports, together with anticoagulant and anticomplementary properties of polysaccharides discussed above, indicated the pharmaceutical significance of macromolecules of Artemisia species.

\section{Antifeedant, insecticidal, and mosquito repellent}

The antifeedant components from Artemisia genus are principally aromatic compounds with an unsaturated side chain. For example, the components from $A$. capillaris inhibiting the feeding to the larvae of the cabbage butterfly were methyleugenol (69), capillarin (76), and capillin (77) (34). The insect repellents of Artemisia origin are usually widespread volatile substances as exemplified by 9-hydroxy-1,8-cineole from A. austriaca and dimethyl phthalate in the oil of several Artemisia species (19, 99).

\section{Allelopathy}

The allelopathic chemicals detected in Artemisia species are acetylenes, mono- and sesquiterpenes. Artemisinin and its semi-synthetic analogues such as $\mathbf{2}$ were shown recently to be plant growth inhibitors (85). This work demonstrated the possibility that artemisinin-related compounds can be used as agricultural agent(s) such as herbicide. Capillin (77) from roots of A. capillaris was found to be a seed (millet, cabbage, pansy and carrot) germination inhibitor (35). In contrast to the growth inhibition, capillarol (68) from A. capillaris promoted at $5 \times 10^{-4} \mathrm{M}$ rice root growth to $180 \%$ of the control (36). Since the side chain of $\mathbf{6 8}$ is quite similar to that of abscisic acid, it could be postulated that the $\alpha, \beta$-unsaturated carbonyl moiety is involved in the plant growth promotion activity.

\section{Conclusions}

The growing significance of natural products in drug discovery and development is obvious as illustrated dramatically by Cragg et al. (93). In morphology, the Artemisia genus is endowed with head-like inflorescences and is considered to be one of the most evolutionary taxa in the Dicotyledonae. This advancement in taxonomy may increase the chemical diversity as the advanced species may synthesize more complex (cyclized, rearranged and/or oxygenated) secondary metabolites (1). This hypothesis has been reinforced by the reported phytochemical results describing the presence of diversified constituents in the Artemisia species. As the investigation continues, this genus may prove to be a richer source of lead compounds needed for the development of new chemotherapeutical and/or agricultural agents.

However, most of the reported biological studies of Artemisia constituents and extracts were carried out in vitro. Mean- 
while, a lot of isolates from the genus have failed when tested biologically. More biological and chemical attention is highly desired.

\section{Acknowledgements}

Grants for RXT from the National Natural Science Foundation (No. $39670873 \&$ 39725033) and the Doctoral Training Programme (No. 9628418) are gratefully acknowledged. The authors are very grateful to Prof. Dr. Adolf Nahrstedt (the editor-in-chief of the journal) for his encouragement and technical instructions about preparation of this manuscript.

\section{References}

${ }^{1}$ Kelsey, R. G., Shafizadeh, F. (1979) Phytochemistry 18, 1591 - 1611.

2 How, F.-C. (1982) A Dictionary of the Families and Genera of Chinese Seed Plants, Second Edition, pp. 44-45, Science Press, Beijing, P. R. China.

3 Vasanth, S., Gopal, R. H., Kundu, A. B. (1991) Indian Drugs 28, $170-177$.

${ }^{4}$ Cubukcu, B., Bray, D. H., Warhurst, D. C., Mericli, A. H., Ozhatay, N., Sariyar, G. (1990) Phytother. Res. 4, 203 - 204.

${ }^{5}$ Bergendorff, O.. Sterner, O. (1995) Planta Med. 61, 370-371.

${ }^{6}$ Chemesova, I. I., Belenovskaya, L. M., Stukov, A. N. (1987) Rastit. Resur. 23, 100 - 103; Chem. Abstr. (1987) 106, $207296 \mathrm{~d}$.

7 Ikram, M., Shafi, N., Mir, L., Do, M. N., Nguyen, P., Le Quesne, P. W. (1987) Planta Med. 53, 389.

8 Qinghaosu Antimalarial Coordinating Research Group (1979) Chin. Med. J. 92, $811-816$.

${ }^{9}$ Kasymov, Sh. Z., Ovezdurdyev, A., Yusupov, M. I., Sham'yanov, I. D., Malikov, V. M. (1986) Khim. Prir. Soedin. 22, 636.

${ }^{10}$ Liu, K., Chiung, S. C., Yang, S. L., Roberts, M. F., Elford, B. C., Phillipson, J. D. (1992) Plant Cell Rep. 11, 637-640.

1 Huang, L., Liu, J. F., Liu, L. X., Li, D. F., Zhang, Y., Niu, H. Z., Song, H. Y., Zhang, C. Y., Liu, X. H., Tu, Y. Y. (1993) Zhongguo Zhongyao Zazhi 18, 44-48.

12 Lin, J. Y., Chen, T. S., Chen, C. S. (1994) Jpn. Kokai Tokkyo JP 06,135,830 [94,135,830]; (1994) Chem. Abstr. 121, 73894w.

13 Stiles, L. H., Leather, G. R., Chen, P. K. (1994) J. Chem. Ecol. 20, $969-978$.

14 Shukla, A., Farooqui, A. H. A., Shukla, Y. N. (1991) Indian Drugs 28, $376-377$.

${ }^{15}$ Zheng, G. Q. (1994) Planta Med. 60, 54-57.

${ }^{16}$ Agari, S., Fukuhara, K., Hori, Y., Manabe, S., Watanabe, W. (1995) Jpn. Kokai Tokkyo Koho JP 07,206,839 [95,206,839]; (1995) Chem. Abstr. 123, 350229r.

17 Zhong. Y. Y., Cui, S. L. (1992) Zhongguo Zhongyao Zazhi 17, $353-$ 354; (1992) Chem. Abstr. 117, $219821 \mathrm{~m}$.

18 Yoshikawa, M., Shimada, H., Matsuda, H., Yamahara, J., Murakami, N. (1996) Chem. Pharm. Bull. 44, 1656-1662.

19 Tabata, M., Watanabe, k., Takada, Y. (1995) Jpn. Kokai Tokkyo JP 07,215,807 [95,215,807]; (1995) Chem. Abstr. 123, 332785g.

20 Zafra-Polo, M. C., Blazquez, M. A. (1991) Phytother. Res. 5, 91 - 93.

21 Wang, Y., Toyota, M., Krause, F., Hamburger, M., Hostettmann, K. (1990) Phytochemistry 29, $3101-3105$.

22 Wahyuono, S., Hoffmann, J. J., McLaughlin, S. P. (1992) Fitoterapia 63, 368.

23 Martin, M. L., Moran, A., Carron, R., Montero, M. J., Roamn, L. San (1988) J. Ethnopharmacol. 23, 285-290.

24 Jiang, J. Y., Xu, Q., Wang, R., Li, P. Z. (1992) Zhongguo Yaoke Daxue Xuebao 23, 283-286; (1993) Chem. Abstr. 118, 182889g; and related refs. cited therein.

25 Matsumoto, T., Katsuya, H., Matsumoto, A., Tokuda, H. (1992) Jpn. Kokai Tokkyo Koho JP 03,287,528 [91,287,528]; (1995) Chem. Abstr. 116, 113505a.

26 Kiso, Y., Ogasawara, S., Hirota, K., Watanabe, N., Oshima, Y., Konno, C., Hikino, H. (1984) Planta Med. 50, 81 - 85.
27 Okada, Y., Miyauchi, N., Suzuki, K., Kobayashi, T., Tsutsui, C., Mayuzumi, K., Nishibe, S., Okuyama, T. (1995) Chem. Pharm. Bull. 43, $1385-1387$.

28 Okada, Y., Miyauchi, N., Suzuki, K., Kobayashi, T., Tsutsui, C., Mayuzumi, K., Okuyama, T. (1994) Nat. Med. 48, 324-329.

29 Yamahara, J., Kobayashi, G., Matsuda, H., Katayama, T., Fujimura, H. (1989) J. Ethnopharmacol. 26, 129-136.

30 Yamahara, J., Kobayashi, G., Matsuda, H., Katayama, T., Fujimura, H. (1989) Chem. Pharm. Bull. 37, 1297 - 1299.

31 Okuno, I., Uchida, K., Nakamura, M., Sakurawi, K. (1988) Chem. Pharm. Bull. 36, $769-775$.

32 Su, J.-D., Osawa, T., Namiki, M. (1986) Agric. Biol. Chem. 50, 199 203.

33 Jang, M.-H., Wu, T.-S., Su, J.-D. (1996) Shipin Kexue (Taipei) 23, 594-607; (1996) Chem. Abstr. 125, 243070b.

${ }^{34}$ Huang, H. C., Chu, S. H., Chao, P. D. L. (1991) Eur. J. Pharmacol. 198, $211-213$.

35 Yano, K. (1987) J. Agric. Food Chem. 35, 889-891.

36 Yano, K., Ishizu, T. (1994) Phytochemistry 37, 689-690.

37 Ueda, J., Yokota, T., Takahashi, N., Yoshida, M., Kato, J. (1986) Agric. Biol. Chem. 50, 3083-3086.

38 Ueda, J., Yamaguchi, I., Takahashi, N., Kato, J. (1987) Agric. Biol. Chem. 51, 595-596.

39 El-Sayed, A. M., Aboutabl, E. S. A., Elazzouny, A. A. (1988) Egypt. J. Pharm. Sci. 29, $43-51$.

${ }^{40}$ Guerreiro, E., Garcia, E. E., Pestchanker, M. I., Enriz, R. D., Rodriguez, A. M., Maria, A., Wendel, G. H. (1995) Nat. Prod. Lett. 6 , $269-280$.

41 Giordano, O. S., Guerreiro, E., Pestchanker, M. J., Guzman, J., Pastor, D., Guardia, T. (1990) J. Nat. Prod. 53, 803-809.

42 Zheng, W. F., Tan, R. X., Yang, L., Liu, Z. L. (1996) Spectroscopy Letters 29, $1589-1597$.

43 Zheng, W. F., Tan, R. X., Yang, L., Liu, Z. L. (1996) Planta Med. 62, $160-162$.

44 Kim, S. S., Lee, C. K., Kang, S. S., Jung, H. A., Choi, J. S. (1997) Arch. Pharmacal Res. 20,148-154.

45 Abdalla, S. S., Abu-Zarga, M. H. (1987) Planta Med. 53, 322 - 324.

46 Abu-Niaaj, L., Abu-Zarga, M., Sabri, S., Abdalla, S. (1996) Int. J. Pharmacogn. 34, 134-140; and related references cited therein.

47 Okuda, T., Hatano, T., Agata, I., Nishibe, S., Kimura, K. (1986) Yakugaku Zasshi 106, 894-899.

48 Appendino, G., Gariboldi, P., Menichini, F. (1991) Fitoterapia 62, $275-276$.

49 Banerji, A., Luthria, D. L., Kokate, S. D. (1990) Indian J. Exp. Biol. $28,588-589$.

50 Kim, Y. S., Roh, J. E., Ann, H. S., Park, H. K. (1992) Yakhak Hoechi 36, 350 - 356; (1994) Chem. Abstr. 121, 198947x.

51 Zhao, Q. C., Kiyohara, H., Yamada, H. (1994) Phytochemistry 35, 73 - 77; and related references cited therein.

52 Liu, C. X., Ye, G. Z. (1991) Phytother. Res. 5, 182- 184.

53 Lee, K. R., Hong, S. W., Kwak, J. H., Pyo, S., Jee, O. P. (1996) Arch. Pharmacal Res. 19, $231-234$.

${ }^{54}$ Gu, P. L. (1994) Zhongcaoyao 25, 633-634; (1995) Chem. Abstr. 122, 209756h.

55 Manadilova, A. M., Adiyatova, Zh. F., Kunaeva, R. M. (1987) Izv, Akad. Nauk. Kaz. SSR, Ser. Biol. (2), 26-29; (1987) Chem. Abstr. 107, 36667q.

56 Mamadilova, A. M., Danilenko, M. P., Esyrev, O. V., Kunaeva, R. M. (1990) Prikl. Biokhim. Mikrobiol. 26, 101-107; (1990) Chem. Abstr. 112, 174694a.

${ }^{57}$ Mamadilova, A. M., Danilenko, M. P., Kunaeva, R. M., Esyrev, O. V. (1988) Izv. Akad. Nauk Kaz SSR, Ser Biol. (2), 87-89; (1988) Chem. Abstr. 109, 69332w.

58 Farmer, E. E., Ryan, C. A. (1990) Proc. Natl. Acad. Sci. U.S.A. 87, $7713-7716$.

59 Kojima, Y., Konno, S., Tamamura, S., Hashimoto, T. (1980) Ger. Offen. 3,000,521; (1981) Chem. Abstr. 94, 52919s.

60 Gilani, A. H., Janbaz, K. H. (1995) Gen. Pharmacol. 26, 309-315. 
61 Graven, E. H., Deans, S. G., Svoboda, K. P., Mavi, S., Gundidza, M. G. (1992) Flavour Fragrance J. 7, $121-123$; (1992) Chem. Abstr. 117, $147191 f$.

62 Abu-Zarga, M., Qausasmeh, R., Sabri, S., Munsoor, M., Abadalla, S. (1995) Planta Med. 61, 242-245.

63 Lim, S.-U., Seo, Y.-H., Lee, Y.-G., Baek, N.-I. (1994) Han'guk Nonghwa Hakhoechi 37, 115-123; (1995) Chem. Abstr. 122, $156266 q$.

64 Kim, Y.-S., Kim, M.-N., Kim, J.-O., Lee, J. H. (1994) Han'guk Nonghwa Hakhoechi 37, 994-1000; (1995) Chem. Abstr. 122, $182943 \mathrm{c}$.

65 Ryahovskaya, T. V., Ushbaeva, G. G., Zhemaletdinov, F. G. (1989) Rastit. Resur. 25, 249-253; (1989) Chem. Abstr. 111, 70445h.

66 Mehrotra, S.,Rawat, A. K. S., Shome, U. (1993) Fitoterapia 64, 65 68.

${ }^{67}$ Charchari, S., Dahoun, A., Bachi, F., Benslimani, A. (1996) Riv. Ital. EPPOS (18), 3-6; (1996) Chem. Abstr. 125, 190390x.

68 Tantaoui-Elaraki, A., Ferhout, H., Errifi, A. (1993) J. Essent. Oil Res. 5, 535-545.

69 Ranjan, K. S., Prasad, G., Sinha, A. K. (1991) Natl. Acad. Sci. Lett. (India) 14, 241 - 243; (1992) Chem. Abstr. 116, 124736c.

70 Um, K.-J., Chung, M.-H. (1995) Saengyak Hakhoechi 26, 390 - 410; (1996) Chem. Abstr. 124, 279086e.

${ }^{71}$ Koo, K. A., Kwak, J. H., Lee, K. R., Jee, O. P., Woo, E. R., Park, H. K., Youn, H. J. (1994) Arch. Pharmacal Res. 17, 371 - 374.

72 Sharatikov, A. S., Prishchep, T. P., Vengerovskii, A. I., Taran, D. D., Beresovskaya, T. P., Kalinkina, G. I., Serykh, E. A. (1986) Khim.Farm. Zh. 20, 585 - 588; (1986) Chem. Abstr. 105, 35306t.

73 Swiader, K., Lamer-Zarawska, E. (1996) Fitoterapia 67, 77- 78.

74 Koikawa, Y., Suetsugu, K., Tanaka, H., Shiba, A. (1994) Jpn. Kokai Tokkyo JP 06 24,937 [94 24,937]; (1994) Chem. Abstr. 120, 279863y.

75 Yun, K. W., Kil, B. S., Han, D. M. (1993) J. Chem. Ecol. 19, $2757-$ 2766.

76 Park, J.-C, You, Y.-B, Lee, J.-H, Kim, N.-J. (1994) Han'guk Yongyang Siklyong Hakhoechi 23,671 - 674; Chem. Abstr. 121, 271619y.

77 Park, J.-C., You, Y.-B, Lee, J.-H, Kim, N.-J. (1994) Han'guk Yongyang Siklyong Hakhoechi 23,116-119; Chem. Abstr. 121, 148576e.

78 Yun, K. W., Kil, B. S. (1992) J. Chem. Ecol. 18, 1933 - 1940.

79 Gilani, A. H., Janbaz, K. H. (1993) Gen. Pharmacol. 24, 1455- 1458.

80 Zhang, H. D. (1994) Faming Zhuanli Shenqing Gongkai Shuomingshu CN 1,078,393; (1994) Chem. Abstr. 121, 42742r.

81 Jang, W. Y., Lee, K. R., Jee, O. P., Yoo, S. J., Kim, Y. C., Kim, S. Y. (1993) Yakhak Hoechi 37, 182-186; (1993) Chem. Abstr. 119, 262462y.

82 Weaver, D. K., Phillips, T. W., Dunkel, F. V., Weaver, T., Grubb, R. T., Nance, E. L. (1995) J. Chem. Ecol. 21, 127-142.

83 Bharel, S., Gulati, A., Abdin, M. Z., Srivastava, P. S., Jain, S. K. (1996) Fitoterapia 67, 387-402.

84 O'Brien, C. (1996) Nature 383, 286.

${ }^{85}$ Bagchi, G. D., Jain, D. C., Kumar, S. (1997) Phytochemistry 45, 1131 - 1133.

86 Beekman, A. C., Barentsen, A. R. W., Woerdenbag, H. J., Uden, W. V., Pras, N., Konings, A. W. T., El-Feraly, F. S., Galal, A. M., Wikström, H. V. (1997) J. Nat. Prod. 60, 325 - 330.

87 Liersch, R., Soike, H., Stehr, C., Tüllner, H.-U. (1986) Planta Med. $52,387-390$

88 Luo, S. D., Ning, B. M., Hu, W. Y., Xie, J. L. (1991) J. Nat. Prod. 54, $573-575$.

${ }^{89}$ Ju, C. Q., Chen, K., Shi, Q., Kikuokie, R. E., Cheng, Y. C., Lee, K. H. (1994) J. Nat. Prod. 57, 42 - 51

${ }^{90}$ Fesen, M. R., Pommier, Y., Leteurtre, F., Hiroguchi, S., Yung, J., Kohn, K. W. (1994) Biochem. Parmacol. 48, 595-608.

91 Yano, K., Tanaka, N. (1995) Biosci., Biotechnol,, Biochem. 59, $1130-1132$.

92 Myahara, R., Yamato, M., Nakajima, N., Taguchi, S. (1992) Jpn. Kokai Tokkyo JP 04 169,526 [92, 169.526]: (1992) Chem. Abstr. $117,184886 g$.
93 Cragg, G. M., Newman, D. J., Snader, K. M. (1997) J. Nat. Prod. 60, $52-60$.

94 Shi, R. Y., Kim, J. O., Choi, S. U. (1997) Planta Med. 63, 383- 385.

95 Hashidoko, Y. (1996) Phytochemistry 43, 535-549.

96 Khan, M. M. A. A., Jain, D. C., Bhakuni, R. S, Zaim, M., Thakur, R. S. (1991) Plant Sci. (Limerick, Irel.) 75, 161 - 165.

97 Rahalison, L., Hamburger, M., Hostettmann, K., Monod, M., Frenk, E., Gupta, M. P., Santana, A. I., Correa, A. M. D., Gonzalez, A. G. (1993) Int. J. Pharmacog. 31, 68-76.

98 Roth, R. J., Acton, N. (1989) J. Nat. Prod. 52, 1183 - 1185.

99 Hwang, Y. S., Wu, K.-H., Kumamoto, J., Axelrod, H., Mulla, M. S. (1985) J. Chem. Ecol. 11, 1297 - 1306.

\section{Prof. R. X. Tan}

Institute of Biotechnology

Department of Biological Science \& Technology

Nanjing University

Nanjing 210093

P. R. China 